\title{
Technical Efficiency and Technical Change in Africa: The Role of Money from the Diasporas
}

\author{
Gloria Clarissa O. Dzeha ${ }^{1}$, Joshua Yindenaba Abor $^{2}$, Festus Ebo Turkson ${ }^{3} \&$ Elikplimi Komla Agbloyor ${ }^{4}$ \\ ${ }^{1}$ Department of Banking and Finance, Central Business School, Central University, Tema, Ghana \\ ${ }^{2}$ Department of Finance, University of Ghana Business School, University of Ghana Legon Accra, Ghana \\ ${ }^{3}$ Department of Economics, University of Ghana Legon Accra, Ghana \\ ${ }^{4}$ Department of Finance, University of Ghana Business School, University of Ghana Legon Accra, Ghana \\ Correspondence: Gloria Clarissa O. Dzeha, Department of Banking and Finance, Central Business School, \\ Central University, P.O. Box 2305 Tema, Ghana. Tel: 233-244-855-890. E-mail: gdzeha@central.edu.gh; \\ gloriadzeha@gmail.com
}

Received: March 16, 2018

Accepted: June 21, 2018

Online Published: June 25, 2018

doi:10.5539/ijef.v10n7p177

URL: https://doi.org/10.5539/ijef.v10n7p177

\begin{abstract}
Based on evidence from the literature that the relationship between remittances and total factor productivity (TFP) is inconclusive, we employ the non-parametric Malmquist productivity index - Data Envelope Analysis to decompose total factor productivity (TFP) into technical change and technical efficiency and further investigate the effect of remittances on the technical change and technical efficiency. We employ the Seemingly Unrelated Regression estimation (SUR) technique in a panel of twenty-three African remittance recipient countries across a twenty-three-year period (1990-2013). We show that remittances received by households have a positive and significant impact on technical efficiency but no significant on technical change (innovativeness). We further show that remittances received by skilled labour is significant to technical efficiency but has a lowering effect on technical efficiency.
\end{abstract}

Keywords: remittance, total factor productivity, technical change, technical efficiency, Seemingly Unrelated regression (SUR)

\section{Introduction}

\subsection{Backgound}

Money from the Diasporas is basically the remittances that the 30 million Africans leaving outside of their home countries send to their families and other relations back home for use. Remittances from the Diasporas into Africa continue to increase. It is the most predictable inflow among other official public and private capital inflows. Total money transfers by African migrants to their country of origin surged by $3.4 \%$ to $\$ 35.2$ billion, in 2015 (World Bank, 2016). Remittances although household receipts, the Monterrey consensus in 2012 identified it as an alternate funding for development in Africa. Remittances cushion household consumption expenditure and compensate for the productivity and efficiency losses which partly arise from the 'brain drain' associated to it and low human resource quality (Adams, Cuecuecha, \& Page, 2009).

Technical efficiency requires the optimum combination of factor inputs to produce goods and services whiles technical change refers to innovations and improvements in the design or quality of new capital goods or intermediate inputs (OECD Glossary statistics terms). Will migrants' remittances fill the gap as an alternative source of finance needed to employ other factor inputs to enhance efficiency and innovation in Africa?

The extant literature however has not established the direct relationship among remittance, technical efficiency and technical change (innovation). In this paper, we contribute to methodology in the remittance studies by first decomposing total factor productivity into technical efficiency and technical change. Secondly, we examine the effect of remittances on technical efficiency and technical change separately. We further discuss investigations done on the interactive effects of remittance and human capital on technical efficiency and technical change. The rest of the paper is structured as follows: as part of section 1 in 1.2 we discuss the stylized facts, 1.2.1 briefly examines Africa's situation, and an understanding into the relationship between 1.2.2 technical change and 
remittances and 1.2.3 technical efficiency and remittance as well as the theories that undergird these thoughts. In section 2 we review existing literature, section 3 includes methodology, econometric estimation and data description. Section 4 is discussion of results and section 5 concludes and provides recommendations.

\subsection{Stylized Facts}

\subsubsection{Africa}

Only few African countries prove to be productive (Seychelles, Equatorial Guinea, Algeria, Tunisia), the rest are still struggling up the productivity ladder, besieged with mass unemployment (ACET, 2016). In 2014, Seychelles and Equatorial Guinea record income per capita of \$25,439.92 and \$19,818.11 as against Burundi and Malawi's of \$336 and \$223 respectively (Economic development reports, 2015). African governments receive millions of dollars yearly in aid from capital rich countries all over the world. These aids have not been efficiently applied by governments in a manner that enhances Africa's lot compared to other countries on other continents (Aid for Africa report, 2015).

Africa's quest to catch-up in development is at the expense of cash and the lack of it makes capital expensive and often a mirage for countries with low-efficiency cycle and lack of innovative prowess. Danquah and Ouattara (2014) decompose Total Factors Productivity (TFP) into technical efficiency and technical change and show they are crucial to in an economy. Macro-economic consequences show that whiles remittances may affect TFP, ascertaining the component of TFP which is significantly affected by remittance inflow is vital (Monterey, 2002).

\subsubsection{Technical Change and Remittance}

Several economies are confronted with setbacks of cyclical fluctuation at the expense of neglecting technical change basically beyond the Great Depression (Jewkes, Sawers, \& Stillerman, 1956). The core Schumpeter's theory on development is technical change. It stresses innovation as the source of dynamism in capitalism. Technical change in literature is anchored two theoretical approaches- the "Demand pull" and the "Technology push" which defines technology as an autonomous or quasi-autonomous factor at least in the short run (Dosi, 1982).

Rosenberg and Mowery (1978) further explain the 'demand-pull' in the light of 'recognition of needs' by the productive unit in a market. It explains that in at any given time, needs of consumption and intermediate goods must be met. Meeting these needs create targets which are met through the deployment of technological prowess and effort on the part of producers. These demand patterns send signals of desire, taste and preference of consumers. The income elasticity of demand in an economy is different giving the relative price of the desired commodity. The theory argues that the growth in income reduces budget constraint of consumer propelling manufacturers to increase their capacity to ride on the "utility dimensions" advantage. These serve an incentive for innovativeness to satisfy consumer by bringing to the market, new and improved goods (Dosi, 1982).

Intuitively, remittances augment disposable income and expanding household consumption of goods and services. Stahl and Arnold (1986) show that remittances into Asia are mostly spent on home made goods and services thus it provides the impetus for the growth of local industries and the economy as a whole. Remittances thus increase the prosperity of recipients to expand their consumption expenditure which affect demand invariably forcing producers to innovate to meet demand as purported by (Myers \& Marquis, 1969).

"Technological push" stems from changes in market conditions that affect demand patterns. The relative distributive shares in costs of production enable producers to follow technological paths at various levels of their production process. Dosi (1982) defines technology from the "Technological push" view point as an acquisition of knowledge both "practical" and "theoretical" including the know-how into methods, procedures, experience through successes and failures and also of course insight into the build-up of physical devices and equipment. Remittance comes in handy for recipients. It affords the ability to access education, training and skill acquisition which enables individual to embrace technical change or innovations.

\subsubsection{Technical Efficiency and Remittance}

Remittances are invested in significant proportions that lead to capital accumulation (Amuedo-Dorantes \& Pozo, 2006; Adams, 2007; Dzeha et al., 2016) although empirical credence show that remittances are consumed (Martin, 1991). Remittances as capital affect investment through the Keynes theory of 'marginal efficiency effect'. Keynes theory of "the marginal efficiency of capital explains that equal to the rate of discount is the present value of the series of annuities given as the returns expected from the capital asset during its life". The theory explains that in financing investments, households and firms will either borrow or reduce savings. However, if interest rates are lower, it becomes cheaper to borrow as savings give a lower return making investment relatively more attractive. 
Remittances through the banks serve as a cheaper source of funds for the banks hence interest rate on such funds are much reduced leading to an increase in investments. It also has the propensity of loosening out credit to domestic businesses. Studies have shown that the mechanisms through which credit can impact growth is the productivity channel. Levine (2004) shows that financial operations involve higher savings, greater investment, technological innovations and productivity gains. Remittances enhance financial development. Schumpeter (1912), Bagehot (1873) explain that financial development invariably enhances TFP growth through efficient allocation and re-allocation of capital. The re-allocative mechanism involving the process of creative destruction hinges on the shifting of capital from industries with deteriorating growth to others with good growth prospects.

Financial frictions and lower levels of TFP growth of developing countries is explained by the misallocation of resources across productive units (Hsieh \& Klenow, 2007; Restuccia \& Rogerson, 2007). However, remittances through the financial institutions increase financial development and reduce financial frictions. They decrease transaction and information costs associated with capital reallocation. They also boost TFP growth (Levine, 1997; Bencivenga, Smith, \& Starr, 1995).

Financial restrictions indeed influence inefficient allocation across with differential productivities (Greenwald, Kohn, \& Stiglitz, 1990; Fisman \& Love, 2004; Aghion et al., 2005; Hartmann et al., 2007; Buera \& Shin, 2008; Buera, Kaboski, \& Shin 2008). Remittances therefore enhance technical efficiency as they reduce the cost of funds spurring into more productive ventures.

\subsection{Review of Literature}

TFP is the single most important determinant of cross-country per capita income differences, business cycle frequencies and economic growth over the longer term (Comin, 2006). Solow (1956) explains TFP is that portion of output not explained by the amount of inputs used in production. It is determined by how efficiently and intensely the inputs are utilized in a production process. Klenow and Rodriguez-Clare (1997) and Hall and Jones (1999) confirm that majority of the gaps in income per capita between rich and poor countries are attributable to large cross-country differences in TFP.

A country's poverty does not guarantee its catch-up on growth. Critically, it is 'Social Capabilities' including ability to attract capital, absorb new technology and participate in global markets (Abramovitz, 1986). These are essential for an economy's catch-up on growth. Remittances increase per capita income based in developing countries (Pradhan et al., 2008). Cross-country differentials in TFP levels are attributable to differentials in efficient use technologies in each country. Barajas, Chami, Fullenkamp, Gapen, and Montiel (2009) reveal that remittances affect TFP growth through efficient domestic investment. Remittances are inexpensive capital and affect the domestic productive sectors by producing dynamic production externalities which affect TFP in an economy (Barajas et al., 2009). This production externalities dynamism may be beneficial or detrimental.

Remittances impact TFP through the expansion of the quantity of funds flowing through the banking system (Aggarwal et al., 2006). Remittances are associated with higher ratios of banking deposits and credit to GDP; this affects the allocation of capital by the financial system (Ketkar \& Ratha, 2005). Remittances enhance efficiency of investment by improving financial intermediation and GDP growth when financial markets are relatively underdeveloped. Remittances loosen the credit constraints imposed on households by a small financial sector (Ratha, 2007).

Large remittance inflows undermine good domestic governance by reducing the incentives for private citizens to monitor domestic government's policy performance, negative implications on the quality of domestic environment and adversely effects TFP growth and production inputs (Abdih et al., 2012). Measuring TFP using growth accounting (Senbetta, 2013; Fayissah \& Nsiah, 2010; Bettin \& Zazzaro, 2008) show remittances impact TFP positively. Elucidating the direct impact of remittance on the components of TFP is ignored. Investigating the extent to which remittances impact technical change and efficiency will be informative.

\section{Methodology}

\subsection{Malmquist Productivity Index}

Notwithstanding the major setbacks with the growth accounting approach (also known as the residual approach) (Solow, 1956), it is the mainstay in empirical studies for measuring total factor productivity. Growth accounting approach assumes that all the units of production are efficient and does not distinguish between technical progress and changes in technical efficiency. The discrete modification for technical improvement and efficiency change that accompanies labour or capital stock is completely ignored in the growth accounting approach.

Addressing this deficiency, Debreu (1951), Koopmans (1951), and Farell (1957) employ the frontier approach to their work to rectify this setback. Generally, the frontier approach is viewed mainly under two broad categories: 
the parametric-stochastic and non-parametric-deterministic. Although the specification of the functional form of the production function as well as the distributions of the stochastic parts is required under the parametric-stochastic frontier analysis (SFA), it is considered robust against measurement errors. The nonparametric-deterministic method data envelopment analysis (DEA), however, employs the use of linear programming methods to fit a piecewise linear quasi-convex hull around the data and does not require functional form assumptions or distributional assumptions although more sensitive to outliers.

Both the parametric SFA and the non-parametric Malmquist productivity index have been employed in the growth literature with respect to the measurement of productivity and its components - technical change and technical efficiency change. However, it is worth noting that results of most empirical studies employing the SFA show that estimates of TFP growth and components vary in sign and magnitudes according to different econometric specifications.

In some cases, model specifications under the SFA are counter intuitive producing results which are not consistent with the empirical literature (Kumbhakar \& Wang, 2005; Garcia et al., 2008). The Malmquist productivity index method appears to be more common in the study of productivity of nations than the SFA (Färe et al., 1994; Taskin \& Zaim, 1997; Maudos et al., 1999; Rao \& Coelli, 1999; Krüger, 2003; Headey et al., 2010; Danquah \& Ouattara, 2014). Lovell (1996, p. 329), for instance, finds the Malmquist productivity index approach based on the data envelopment analysis (DEA), "to have achieved a more satisfactory reorientation toward productivity measurement than the SFA has".

Nonetheless, in this paper, we use the output-based Malmquist productivity index approach in a macroeconomic context, where, the countries are producers of output (real GDP) given inputs (physical capital stock and labour), to compute technical change, efficiency change and productivity growth for the countries in our sample as done by Vandenbussche et al. (2006) in the decomposition of TFP.

\section{2 understanding the Malmquist Productivity Index and Data Envelopment Analysis (DEA)}

Employing the Malmquist index approach, as put forth by Färe et al. (1994) and Coelli and Rao (1999), we measure the total factor productivity (TFP) growth in different countries. The Malmquist index method utilises the 'data envelopment analysis' (DEA) to build a piece-wise frontier in a linear production equation for each country in each year in the sample. It is the DEA procedure employed in the calculating of the Malmquist productivity index, grounded on the premise of the presence of a production technology which alters a multi-dimensional vector of input, for instance $x$, into a multi-output vector, of say $y$.

This is underpinned with the fact that the technology of the production function is presumed to address the basic axioms including the most essential properties of (1) weak or strong disposability of outputs and (2) weak or strong disposability of inputs and among others like (3) Possibility of inactivity; (4) closed and bounded production possibility sets; (5) closed input sets; and (6) input and output convexity (Danquah \& Ouattara 2014). Again, this current study also assumes that the constant returns to scale of the production technologies adopted and hence addresses global or local perspectives.

DEA employs input and output data quantities in a linear programming to build a piece-wise linear surface over the data points of the number of countries across the years in the study. Thus the linear programming process is sequentially - one for each country in the study.

It follows therefore that the residual of the frontier approach is attributable by the degree of technical inefficiency of each country. DEA however can be either output-orientated or input-orientated. Appling a constant return to scale (CRS) technology, both of these measures provide the same technical efficiency scores, although they are not always equal when variable returns to scale (VRS) is assumed.

Ideally countries endeavour to generate output by making the most out of their wealth endowments and their sets of given inputs rather than the reverse. In view of this, we adopted the output-orientation approach for study which is more ideal. The linear programming issue of the DEA model therefore, in an output-orientation for $\mathrm{N}$ number of countries for a specific period of time explained for the i-th country is as follows (as cited in Danquah \& Ouattara, 2014):

$$
\begin{gathered}
\operatorname{Max}_{\varphi \gamma} \varphi \\
s t-\varphi y_{i}+Y \gamma \geq 0 \\
x_{i}-X \gamma>0 \\
\gamma>0
\end{gathered}
$$

Thus, $y i$ is a $\mathrm{M} \times 1$ vector of output quantities for the $\mathrm{i}$-th country; 
$x i$ is a $\mathrm{K} \times 1$ vector of input quantities for the $\mathrm{i}$-th country;

$Y$ is a $\mathrm{N} \times \mathrm{M}$ matrix of output quantities for all $\mathrm{N}$ countries;

$X$ is a $\mathrm{N} \times \mathrm{K}$ matrix of input quantities for all $\mathrm{N}$ countries;

$\lambda$ is a $N \times 1$ vector of weights; and $\varphi$ is a scalar.

Holding the input quantities constant, $\varphi$ assumes a value greater than or equal to one, such that $\varphi-1$ is the proportional increase in outputs that could be achieved by the i-th country. $1 / \varphi$ therefore represents the technical efficiency (TE) score which varies between zero and one. Countries that are efficient are on the frontier and record scores that are equal to 1 and countries that are inefficient record scores less than 1 . Thus, for each country employed in the sample, the linear programming described earlier will have to be solved $\mathrm{N}$ number of times.

In the decomposition and computing of the Malmquist TFP index measures using the DEA, we compute the ratio of the distances of each data point relative to a common technology. Subsequent to Färe et al. (1994), the output-orientated approach of the Malmquist TFP change index between period s which is the base period and the period $t$ is given by the equation Aii.

$$
m_{0}\left(y_{s} y_{t} x_{s} x_{t}\right)=\left[\frac{d_{o}^{s}\left(y_{t}, x_{t}\right) x d_{o}^{s}\left(y_{t}, x_{t}\right)}{d_{o}^{s}\left(y_{s}, x_{s}\right) x d_{o}^{s}\left(y_{s}, x_{s}\right)}\right]^{1 / 2}
$$

From equation Aii $d_{0}^{s}\left(x_{t}, y_{t}\right)$ represents the distance from the period $t$ observation to the period $s$ technology. A value of $m_{0}$ greater than one will indicate positive TFP growth from period $\mathrm{s}$ to period $\mathrm{t}$ while a value less than one indicates a TFP decline. The geometric mean therefore of the two indices of TFP is what is seen in equation Aii, evaluated with respect to period ' $s$ ' in the first technology and the second technology with respect to period ' $t$ '. Equally the productivity index can be rewritten as in equation Aiii. The ratio outside the square brackets measures the change in the output-oriented measure of Farrell technical efficiency between period $\mathrm{s}$ and $\mathrm{t}$.

$$
m_{0}\left(y_{s} y_{t} x_{s} x_{t}\right)=\frac{d_{0}^{t}\left(y_{t} x_{t}\right)}{d_{0}^{s}\left(y_{s} x_{s}\right)}\left[\frac{d_{0}^{s}\left(y_{t}, x_{t}\right)}{d_{0}^{t}\left(y_{t}, x_{t}\right)} \times \frac{d_{0}^{s}\left(y_{s}, x_{s}\right)}{d_{0}^{t}\left(y_{s}, x_{s}\right)}\right]^{1 / 2}
$$

The other part of the index is a measure of technical change. The required distance measures for the Malmquist TFP index can be calculated using DEA-like linear programs (Färe et al., 1994).

\subsection{Estimation Technique}

We estimate a dynamic panel data model using data on twenty-three African countries for 25 years from the period 1989-2013. Panel data techniques enhance the variability of the data and allow for increase in the degrees of freedom. They also include within-country standard deviation as well as between-country standard deviation being the time variation effect. Our model specification in this study is similar to the work of Zellner (1962) and Danquah and Ouattara (2014) on their empirical growth model. We decompose total factor productivity into its constituent parts; technical change and technical efficiency we employ all two as our dependent variables jointly with remittances as the primary independent variables. The model estimated is given as follows:

$$
y_{i t}=\alpha+\beta_{1} \operatorname{Rem}_{i t}+\beta_{2} \operatorname{Rem} * H C_{i t}+\sum_{j=3}^{N} \beta j X_{i t}+\mu_{i}+\varepsilon_{i t}
$$

Where $y_{i t}$ represents the two dependent variables - technical change, and technical efficiency for country ' $i$ ', subscript ' $t$ ' represents time. $\beta_{1}$ represents the coefficient of international migrants' personal remittances. We obtained the data on Personal remittances from the World Development Indicators. $\beta_{2}$ represents the interactive effect between remittances and human capital. Both remittance and human capital are included in the model to capture their independent effects on technical change and technical efficiency. We expect a positive relation between human capital and all two dependent variables- technical change, and technical efficiency Human capital is measured as secondary school enrolment. We further included the product of remittance and human capital to ascertain the interactive effect of remittance and human capital. $X_{i t}$ is a set of control variables. These control variables have been extensively used in literature.

The expansion of broad money in an economy is usually associated with growth in GDP on one hand and has also the potential of increasing inflation (Mohammed \& Hussain, 2017). We therefore expect that increase in broad money may increase productivity growth and hence show a positive relationship with all the components of TFP. However, we also expect that increase in broad money may ignite an increase in inflation which may impact negatively on TFP. Increase in GDP growth increases productivity (Daskovska, Simar, \& Bellegem, 2010). We expect a positive relationship between GDP growth and technical efficiency.

Polity 2 explains the type of governance that is present in most African countries. The governance type ranges between -9 to 9 . A movement towards -9 represents autocracy type of governance while toward 9 suggests 
democratic type governance. We hypothesize a positive relationship between democratic governance and Productivity. Zerfu (2007) shows that improvement in governance could reduce technical inefficiencies significantly and hence could considerably boost productivity.

We expect that population growth may impact productivity either positively or negatively. Peretto (1998) predicts that steady-state productivity growth does not depend on population size however the crowding-in effect as a result of the increase in population generates dispersion of research and development resources across firms and offsets the positive effects of the scale of the economy on the returns to research and development.

We also include manufacturing value to Gdp from the WDI (2015). We expect manufacturing to impact productivity positively or negatively as it depends on the quality of products and processes. Suh (1985) shows that to increase productivity, there is the need to maximise the value added and lower manufacturing cost. Investment is measured as gross fixed capital formation to GDP. Traditional growth theories predict a positive relationship between investment and productivity.

(Technical change, Technical Efficiency = Remittance, Human Capital, Remittance*Human capital, Broad money, Gdp growth, Polity 2, Population growth, Manufacturing value, investment).

The estimation technique employed in this study is the Seemingly Unrelated Regressions (SUR) model developed by Zellner (1962). The SUR model explains the variation of not just one dependent variable as in the univariate multiple regression models but the variation of a set of a number of dependent variables with an independent and other control variables. In this paper we study if remittance inflows into Africa have the potential of affecting technical change and technical efficiency. We include other control variables that affect technical change and technical efficiency study three dependent variables including technical change(innovation) and technical efficiency and remittance as the main independent variable with other controls as well as the error terms specific to each individual problem.

Geweke (2003, p. 162) explains that the seemingly unrelated regressions (SUR) model is the most widely used econometric model after linear regressions as it provides a simple and useful representation of systems of equations. The SUR model is a collection of two or more regression relations that can be analysed with data on the dependent and independent variables. For many years, the individual regression relations were fitted one by one, usually using least squares techniques and justified by an appeal to single equation estimation optimality properties, e.g. the least squares estimators are best linear unbiased estimators according to the well-known Gauss Markov theorem and maximum likelihood estimators when single equation normal likelihood functions are employed.

Zellner (2006) further explained that when the error terms in the different regression equations are correlated the regression equations are related, not unrelated and that the sample information in other regressions can be employed to improve the precision of estimation of parameters in any given regression equation under a wide range of conditions. The operational SUR therefore is the best linear unbiased estimator for the parameters of the set of regression equations put forward which uniformly dominate the single equation least squares estimators under the broad range of conditions. This Zellner claims was overlooked in the literature during the pre-1962 era. Additionally, the SUR estimator is the best linear unbiased with a normality assumption for the error terms, maximum likelihood and "diffuse prior" Bayesian estimator under frequently encountered conditions. Moreover, by joint analysis of the set of regression equations more precise estimates and predictions are obtained leading to a better solution to many applied problems rather than equation by equation analysis.

The SUR estimator further reduces to single equation least squares estimators when error terms in the different equations are mutually uncorrelated, suggesting that the equations are unrelated. The use of SUR techniques also leads to improved tests of hypotheses regarding regression coefficients' and other parameters' values. Similarly, taking account of the error terms' correlations across equations leads to better predictions of future values of the dependent variables.

The specific regression models estimated together to ascertain the impact of remittance on technical change(innovation) and technical efficiency is thus specified as:

$$
\begin{gathered}
\text { Techch }_{i t} \text { TechEff }_{i t}=\alpha+\beta_{1} \text { Rem }_{i t}+\beta_{2} H C_{i t}+\beta_{3} \text { Rem }^{*} H C_{i t}+\beta_{4} \text { Bm }_{i t}+\beta_{5} \text { Gdpgrowth }_{i t}+\beta_{6} \text { Polity }_{i t}+ \\
\beta_{7} \text { Popgrowth }_{i t}+\beta_{8} \text { Manv }_{i t}+\beta_{9} \text { Invest }_{i t}++\mu_{i}+\varepsilon_{i t}
\end{gathered}
$$

\subsection{Data Description}

We estimate our models employing the SUR estimator which was developed by Zellner (1962). The two dependent variables being estimated together include technical change (Techch) as innovation and technical efficiency (TechEff). Remittance is the primary independent variable. Remittances and other control variables 
were sourced from World Bank - World development indicators, 2015. For the decomposition of total factor productivity; labour, capital and output data were sourced from the Penns World 2015 data. An unbalanced data was employed in the model.

Remittance (RemGdp) is measured as total personal remittance to GDP. Other controls include human capital (HC) measured as secondary school gross enrolment ratio regardless of age. Secondary education completes the provision of basic education that began at the primary level and aims at laying the foundations for lifelong learning and human development, by offering more subject- or skill-oriented instruction using more specialized teachers. Broad money (Bm) measured as broad money to GDP, is the sum of currency outside banks; demand deposits other than those of the central government; the time, savings, and foreign currency deposits of resident sectors other than the central government; bank and traveller's cheques; and other securities such as certificates of deposit and commercial paper. GDP growth measured as annual percentage growth rate of GDP at market prices based on constant local currency with its aggregates based on constant 2005 U.S. dollars.

Polity 2 is an index to measure governance type - from autocracy through to democracy with a range of -9 to 9 . Then population growth (Popgrowth) is measured of annual population growth rate, based on the de facto definition of population, which counts all residents regardless of legal status or citizenship--except for refugees not permanently settled in the country of asylum and who are generally considered part of the population of the country of origin. Manufacturing (manv) is the manufacturing value to GDP and described under economic policy and debt as national accounts shares of GDP among others. Investment is measured as gross fixed capital formation to GDP. All of these variables are sourced from World Bank-WDI 2015.

\section{Empirical Results}

\subsection{Descriptive Statistics and Data Analysis}

In table 1, we first employed descriptive statistics to ascertain the nature of the data being used. The level of technical change (innovation) in selected African countries is averagely 0.996 with variability of 0.07 . It fluctuates between a maximum value of 1.344 and a minimum is 0.788 . The mean technical efficiency however is $1 \%$ and varies across a minimum level of 0.113 and maximum level of 1.615 respectively with standard deviation of 0.09. Again, the average level of remittance receipts over the entire period across the sample countries are $2.9 \%$ of GDP with variability of $3.1 \%$. The highest of total remittance inflows is $15 \%$ of Gdp and the lowest inflow is at $0.002 \%$ across the period of the study.

Human capital ranges between $1.125 \%$ and $2.846 \%$ of gross enrolment, with an average of $1.830 \%$. Broad money to GDP ratio average is 33\% with the highest recorded in about $113.991 \%$ and the lowest recorded $7 \%$. An average GDP growth is $3.969 \%$, the lowest rate is $-36 \%$ and highest growth is $33.736 \%$. Polity 2 average score of 0.443 recorded from autocracy with the score of -9 to democracy with a score of 9 with variability of 5.5. This signifies the anocratic type of governance regime. An anocratic government features an "incoherent mix of democratic and autocratic traits and practices". Population growth has mean of $2.5 \%$ with the lowest rate at $0.342 \%$ whiles the highest of $5.07 \%$. Manufacturing value to GDP is averagely $11.05 \%$. Highest ratio $23.639 \%$ and the lowest is $2.410 \%$. Average Investment to GDP ratio is $19.37 \%$ with the highest and lowest ratios of $38.90 \%$ and $4.562 \%$ respectively.

Table 1. Descriptive statistics

\begin{tabular}{lccrrr}
\hline Variable & Observations & \multicolumn{1}{c}{ Mean } & Std. Dev. & Min & \multicolumn{1}{c}{ Max } \\
\hline Technical Change & 598 & 0.9948378 & 0.066296 & 0.788 & 1.344 \\
Technical efficiency & 598 & 1.002635 & 0.089214 & 0.113 & 1.615 \\
Remittance /Gdp & 598 & 2.912407 & 3.171016 & 0.001778 & 15.4523 \\
Human Capital & 598 & 1.836902 & 0.423221 & 1.124828 & 2.846072 \\
Broad Money / Gdp & 598 & 32.64874 & 20.67437 & 6.546494 & 113.9918 \\
Gdp growth & 598 & 3.969093 & 4.266389 & -36 & 33.73578 \\
Polity2 & 591 & 0.4433164 & 5.488949 & -9 & 9 \\
Population growth & 598 & 2.498221 & 0.732673 & 0.341697 & 5.071227 \\
Manufacturing value/ Gdp & 572 & 11.04982 & 5.015511 & 2.41013 & 23.63966 \\
Investment & 598 & 19.36871 & 6.593949 & 4.562497 & 38.89547 \\
\hline
\end{tabular}

Source: Authors compilation from Penns World Tables and WDI, 2015. 


\subsection{Pairwise Correlations of Variables}

In Table 2, we show the pairwise correlation matrix for the variables that we employed in the empirical analysis. There is generally very low correlation between variables. This suggests that the concern of multicolinearity is generally not an issue with respect to our model specifications. Remittances have positive and significant correlations with both technical change and technical efficiency. It is observed that while human capital is significant to technical change it has negative correlation with technical change. Human capital however is significant and positively correlates with technical efficiency. Remittances do not correlate with human capital significantly. There is a negative correlation between remittances and human capital.

Broad money positively and significantly correlates with technical change and technical efficiency. Growth in GDP correlates to technical change negatively and this is significant but not with technical efficiency. Polity 2 as a measure of type of governance within countries in Africa is significant to both technical change and technical efficiency within the countries but has negative correlation with technical change but a positive correlation with technical efficiency. Population growth in countries is significant to both technical change and technical efficiency but has negative correlation with technical change and technical efficiency. Both manufacturing and investments are significant to technical change and technical efficiency but correlate positively with technical change but negatively with technical efficiency.

Table 2. Pairwise correlation of variables

\begin{tabular}{lccccccccc}
\hline & $\begin{array}{c}\text { Technical } \\
\text { change }\end{array}$ & $\begin{array}{c}\text { Technical } \\
\text { efficient }\end{array}$ & Remittance & $\begin{array}{c}\text { Human } \\
\text { Capital }\end{array}$ & $\begin{array}{c}\text { Board } \\
\text { Money }\end{array}$ & $\begin{array}{c}\text { Gdp } \\
\text { growth }\end{array}$ & \multicolumn{2}{c}{ Population } \\
Prowth & Manufacturing Investment \\
\hline Technical change & 1 & & & & & & & & \\
Technical efficiency & -0.5244 & 1 & & & & & & & \\
Remittance & 0.0149 & 0.0256 & 1 & & & & & & \\
Human Capital & -0.0102 & 0.0149 & -0.1412 & 1 & & & & & \\
Broad Money & 0.0799 & -0.1147 & 0.3352 & 0.3193 & 1 & & & & \\
Gdpgrowth & -0.0926 & 0.2276 & 0.0537 & 0.044 & -0.0214 & 1 & & & \\
Polity2 & -0.0588 & 0.0682 & -0.1545 & 0.1729 & -0.0529 & 0.1264 & 1 & & \\
Poplation growth & -0.0137 & 0.0092 & 0.0203 & -0.4312 & -0.5894 & 0.0642 & 0.0625 & 1 & 1 \\
Manufacturing & 0.0486 & -0.0885 & 0.0934 & 0.0824 & 0.5202 & -0.1079 & -0.2028 & -0.4084 & 1 \\
Investment & 0.0169 & -0.055 & 0.0391 & 0.2292 & 0.2924 & 0.1174 & 0.1112 & -0.1453 & 0.0018 \\
\hline
\end{tabular}

Source: Authors compilation from Penns World Tables and WDI, 2015, Table showing significance levels of $* * * \mathrm{p}<0.01, * * \mathrm{p}<0.05, * \mathrm{p}<0.1$ is in appendix $\mathrm{C}$.

\section{Discussion of Results}

Table 3 exhibits our regression results. We investigate whether remittances significantly promote technical change (innovation) and technical efficiency individually. Furthermore, we show the interactive effect of remittance and human capital on technical change and technical efficiency. We find that remittances indeed are statistically and positively significant to technical efficiency but not technical change (innovation). This finding is in sync with theory, in that remittance expands income available to recipients for the acquisition of improved technologies. Remittance inflows empower recipients financially to specifically acquire the capability of specific applications to maximise efforts needed to yield precisely an outcome successfully in a least possible time.

Table 3. Regression results

\begin{tabular}{lcc}
\hline Variables & Technical Change & Technical Efficiency \\
\hline Remittance/Gdp & -0.0012 & $0.0133^{* * *}$ \\
& $(0.006)$ & $(0.005)$ \\
Human Capital & -0.0034 & $0.0310^{* * *}$ \\
& $(0.009)$ & $(0.008)$ \\
Remittance*Human Capital & -0.0002 & $-0.0056^{* *}$ \\
& $(0.003)$ & $(0.003)$ \\
Broad Money/Gdp & $0.0005^{* *}$ & $-0.0009^{* * *}$ \\
& $(0.000)$ & $(0.000)$ \\
Gdp growth & -0.0005 & $0.0043^{* * *}$ \\
& $(0.001)$ & $(0.000)$ \\
\hline
\end{tabular}




\begin{tabular}{lcc}
\hline Polity2 & -0.0002 & $0.0014^{* * *}$ \\
& $(0.001)$ & $(0.000)$ \\
Population growth & 0.0048 & $-0.0096^{* * *}$ \\
& $(0.004)$ & $(0.003)$ \\
Manufacturing value/Gdp & -0.0004 & 0.0000 \\
& $(0.001)$ & $(0.001)$ \\
Investment & -0.0004 & $-0.0010^{* * *}$ \\
& $(0.000)$ & $(0.000)$ \\
Observations & 565 & 565 \\
Number of country & 23 & 23 \\
\hline
\end{tabular}

Note. Standard errors in parentheses: *** $\mathrm{p}<0.01, * * \mathrm{p}<0.05, * \mathrm{p}<0.1$. Source: Authors compilation.

We find strong evidence indicating that human capital is statistically significant and has a positive effect on technical efficiency. Training and acquisition of skills enhances the extent to which an individual utilises time and applies effort for an intended task or purpose. Educated people are more enlightened and are more effective in the achievement of results to goals and targets set. Efficiency is enhanced as people are trained and acquire the necessary skills that make people effective at whatever they do. This is a confirmation of the findings of Danquah and Ouattara (2014) and Vandenbussche et al. (2006) who argued that the adoption of technology or imitation and innovations involve mostly physical capital which is a skill-intensive activity and also Nelson and Phelps (1966) who argued that a more educated labour force would desire and adopt new technologies faster, consequently closing the technological gap.

Whiles remittances and human capital individually impact technical efficiency positively and significantly, the interactive effect of multiplying remittances with human capital yielded a significantly negative impact on technical efficiency in Africa. Remittances are generally observed to be beneficial to households as they increase disposable income at that level. Ideally remittance receipts have a positive spill over effect into the national economy by augmenting effective demand. The increase in demand stimulates increase in the production of industrial goods and services which invariably increases domestic technical efficiency in production as purported by Skeldon (2002) and Ratha (2003). However, remittances to skilled recipients do not encourage efficiency. Intuitively we presume that remittances to skilled labour augment their available disposable income beyond thresholds that compromises efficient practices.

Broad money is statistically significant to both technical change and technical efficiency however broad money affects technical change positively and technical efficiently negatively. This may be true in view of the fact that broad money being the totality of assets that households and businesses can use to make payments or to hold as short-term investments, such as currency, funds in bank accounts and anything of value resembling money and also being the most inclusive method of calculating money supply. Broad money supports innovativeness but, in most instances, does not lead to greater efficiency. There is a well-established long-run empirical relationship between broad money growth and inflation across a variety of countries and monetary regimes (see for example Benati, 2005; King, 2002).

GDP growth is statistically significant and positively impacts technical efficiency. GDP growth and Productivity move in tandem through their impact on efficiency. Productivity is characterised as the cornerstone of economic growth and development. Increases in productivity allow firms to produce greater output for the same level of input, earn higher revenues, and ultimate generate higher Gross Domestic Product. Productivity is a key driver of economic growth and changes in living standards. Labour productivity growth implies a higher level of output for unit of labour input (Kitov et al., 2008). This can be achieved if more capital is used in production or through improved overall efficiency with which labour and capital are used together, i.e., higher multifactor productivity growth (MFP). Productivity is also a key driver of international competitiveness, e.g. as measured by Unit Labour Costs (ULC).

Our Polity 2 score significantly and positively impacts technical efficiency but has a lowering effect on technical change. From the descriptive statistics in table 1 , a polity 2 score of 0.352 suggest the level of anocracy in the governance system in the African states under the study. We find that the level of anocracy in Africa positively and significantly enhances the level of technical efficiency, but this is the same with technical change as it suggests a detrimental effect.

Population growth also significantly impacts technical efficiency but not technical change. Population growth has a lowering effect on efficiency. These findings are in agreement with Barro and Lee (2010) and they indicate that the large masses of the population in Africa usually do not contribute to TFP growth through the adoption of 
technology as suggested by Vandenbussche et al. (2006) thereby discouraging technical efficiency. We further found that although investment is significant to technical efficiency, investment has the potential of lowering the effect on efficiency.

\section{Conclusion and Recommendations}

Clearly, remittance inflows are very important and significant in enhancing technical efficiency. There is no doubt that ensuring efficiency cannot happen without money. Remittances therefore allow recipients to bring their ideas to life by ensuring efficiency through the optimum use of resources which invariably lead to productivity. Greater efforts must be directed at creating congenial domestic environment that makes it easy for people in the diaspora to send money.

Beyond money, skilled labour is key to efficiency. Governments should target creating avenues for its citizens to be top-performers through the acquisition of knowledge and skill through training necessary for enhancing efficiency. Expanding broad money through the increase of economic activity in a congenial atmosphere must be of great concern to governments. Frantic efforts must be directed at targeting increasing production levels to shoot GDP growth. Governance styles must avoid extremes in autocracy or democracy. Anocracy style of governance encourages efficiency. Much efforts must be targeted at reduction in population growth to encourage efficiency. The direction in future research is to employ primary data on country specific remittance receipts and total factor productivity of that specific country.

\section{Acknowledgments}

Our sincere thanks and appreciation goes to Emmanuel Abbey of the Department of Economics of the University of Ghana and Dr. Haruna Issahaku of Department of Economics and Enterprenerial Studies, University of Development Studies, Tamale, Ghana who assisted in critiquing the manuscript.

\section{References}

Abdih, Y., Chami, R., Dagher, J., \& Montiel, P. (2008). Remittances and Institutions: Are Remittances a Curse? IMF Working Paper 08/29. Washington: International Monetary Fund.

Abramovitz, M. (1986). Catching Up, Forging Ahead and Falling Behind. The Journal of Economic History, The Task of Economic History, 46(2), 385-406. https://doi.org/10.1017/S0022050700046209

Acosta, P. A., Lartey, E. K. K., \& Mandelman, F. (2007). Remittances and the Dutch Disease. Federal Reserve Bank of Atlanta Working Paper No. 2007- 08. Atlanta: Federal Reserve Bank.

Acosta, P. A., Lartey, E. K. K., \& Mandelman, F. (2008). Remittances, Exchange Rate Regimes, and the Dutch Disease. A Panel Data Analysis. Federal Reserve Bank of Atlanta Working Paper No. 2008-12. Atlanta: Federal Reserve Bank.

Adams R. H. Jr. (2007). International Remittances and the Household: Analysis and Review of Global Evidence. World Bank Policy Research Working Paper 4116.

Adams, R., \& Cuecuecha, A. (2010). Remittances, household expenditure and investment in Guatemala. World Development, 38, 1626-1641. https://doi.org/10.1016/j.worlddev.2010.03.003

Africa Centre for Economic Transformation (ACET). 2016.

Aggarwal, R., Demirguc-Kunt, A., \& Martínez Pería, M. S. (2006). Do Workers' Remittances Promote Financial Development? World Bank Policy Research Paper 3957. Washington: World Bank.

Aghion, P. et al. (2005). Volatility and Growth: Credit Constraints and Productivity-Enhancing Investment. NBER Working Paper 11349. Cambridge, United States: National Bureau of Economic Research. https://doi.org/10.1093/acprof:oso/9780199248612.001.0001

Arellano, M., \& Bond, S. R. (1991). Some test of specification of for Panel data: Monte Carlo evidence amd application to employement equations. Review of Economic Studies, 58(2), 277. https://doi.org/10.2307/2297968

Bagehot, W. (1873). Lombard Street: A Description of the Money Market. Homewood, Illinois, United States: Irwin.

Ballard, R. (2004). Migration and development: How to make Migration Work for Poverty Reduction. London: House of Commons International Development Committee.

Baltagi, B. H., \& Kao, C. (2000). Nonstationary Panels, Cointegration In Panels And Dynamic Panels: A Survey. Center for Policy Research Working Paper No. 16. https://doi.org/10.1016/S0731-9053(00)15002-9 
Barajas, A., Gapen, M. T., Chami, R., Montiel, P., \& Fullenkamp, C. (2009). Do workers remittances promote economic growth? IMF Working Paper 09/153, Washington DC: International Monetary Fund.

Barro, R. J., \& Lee, J. W. (2010). A New Data Set of Educational Attainment in the World, 1950-2010. NBER Working Paper, 15902, National Bureau of Economic Research, Inc. https://doi.org/10.3386/w15902

Basu, B., \& Bang, J. T. (2013). Insurance and remittances: New evidence from Latin American immigrants to the US. Migration Letters, 10(3), 383-398.

Basu, B., \& James, T. B. (2014). Insurance and remittances: New evidence from Latin American immigrants to the US. Migration Letters, 10(3), 383-398.

Benati, L. (2005). Long-run evidence on money growth and inflation. Bank of England Quarterly Bulletin, Autumn, pp. 349-55.

Bencivenga, V., Smith, D., \& Starr, R. (1995). Transactions Costs, Technological Choice, and Endogenous Growth. Journal of Economic Theory, 67, 52-177. https://doi.org/10.1006/jeth.1995.1069

Bitros, G. C., \& Panas, E. (2001). Is there an inflation-productivity trade-off? Some evidence from the manufacturing sector in Greece. Applied Economics, 33(15), 1961-1969. https://doi.org/10.1080/00036840110043730

Buera, F., \& Shin, Y. (2008). Financial Frictions and the Persistence of History: A Quantitative Exploration. Los Angeles, United States: University of California-Los Angeles.

Buera, F., Kaboski, J., \& Shin, Y. (2008). Finance and Development: A Tale of Two Sectors. Los Angeles, United States: University of California-Los Angeles.

Comin, D. (2006). Total Factor Productivity. New York University and NBER, August 2006.

Danquah, M., \& Ouattara, B. (2014). Productivity Growth, Human Capital and Distance to Frontier in Sub-Saharan Africa. Journal of Economic Development, 39(4).

Daskovska, A., Simar, L., \& Bellegem, S. (2010). Forecasting the Malmquist productivity index. Journal of Productivity Analysis, 33(2), 97-107. https://doi.org/10.1007/s11123-009-0147-5

Debreu, G. (1951). The coefficient of resource utilization. Econometrica: Journal of the Econometric Society, 273-292. https://doi.org/10.2307/1906814

Färe, R., Grosskopf, S., Norris, M., \& Zhang, Z. (1994). Productivity Growth, Technical Progress, and Efficiency Change in Industrialized Countries. The American Economic Review, 66-83.

Farrell, M. J. (1957). The Measurement of Productive Efficiency. Journal of the Royal Statistical Society, Series A (General), 120, 253-290. https://doi.org/10.2307/2343100

Fayissa, B., \& Nsiah, C. (2010). The Impact of Remittances on Economic Growth and Development in Africa. The American Economist, 55(2), 92-103. https://doi.org/10.1177/056943451005500210

Fisman, R., \& Love, I. (2003). Trade Credit, Financial Intermediary Development, and Industry Growth. Journal of Finance, 58, 353-374. https://doi.org/10.1111/1540-6261.00527

Garcia, F., César De Souza, R., \& Pires, J. O. (2008). Technical Change: It Should Be Positive and Make Sense! Economics Letters, 100, 388-391. https://doi.org/10.1016/j.econlet.2008.03.014

Geweke, J. (2003). Contemporary Bayesian Econometrics and Statistics. Hoboken, NJ: Wiley.

Greenwald, B., Kohn, M., \& Stiglitz, J. (1990). Financial Market Imperfections and Productivity Growth. Journal of Economic Behavior and Organization, 13(3), 321-345. https://doi.org/10.1016/0167-2681(90)90004-W

Hall, R., \& Jones, C. (1999). Why Do Some Countries Produce So Much More Output per Worker than Others? Quarterly Journal of Economics, 114, 83-116. https://doi.org/10.1162/003355399555954

Hartmann, P. et al. (2007). The Role of Financial Markets and Innovation in Productivity and Growth in Europe. European Central Bank. Occasional Paper Series 72. Bonn, Germany: European Central Bank.

Hauner, D., \& Kyobe, A. (2008). Determinants of Government Efficiency. IMF Working Paper, Fiscal Affairs Department, International Monetary Fund WP/08/228 September 2008. https://doi.org/10.5089/9781451870862.001

Headey, D., Alauddin, M., \& Rao, D. (2010). Explaining Agricultural Productivity Growth: An International Perspective. Agricultural Economics, 41, 1-14. https://doi.org/10.1111/j.1574-0862.2009.00420.x 
Hsieh, C., \& Klenow, P. (2007). Misallocation and Manufacturing TFP in China and India. NBER Working Paper 13290. Cambridge, United States: National Bureau of Economic Research. https://doi.org/10.3386/w13290

Ketkar, S. L., \& Ratha, D. (2005). Recent Advances in Future-Flow Securitization. The Financier, 73-102.

King, M. A. (2002). No money, no inflation - the role of money in the economy. Bank of England Quarterly Bulletin, Summer, 162-77.

Kitov, I., \& Kitov, O. (2008). The driving for of labor force participation rate. MPRA Paper 8677, University Library of Munich, Germany.

Klenow, P., \& Rodriguez-Clare, A. (1997). The Neoclassical Revival in Growth Economics: Has it gone too far? In B. Bernanke, \& J. Rotemberg (Eds.), NBER Macroeconomics Annual. Cambridge, MA: MIT. https://doi.org/10.1086/654324

Koopmans, T. C. (1951). Activity Analysis of Production and Allocation. New York.

Kremer, M. (1993). Population Growth and Technological Change: One Million B.C. to 1990. The Quarterly Journal of Economics, 108(3), 681-716. https://doi.org/10.2307/2118405

Krüger, J. J. (2003). The Global Trends of Total Factor Productivity: Evidence from the Nonparametric Malmquist Index Approach. Oxford Economic Papers, 55, 265-286. https://doi.org/10.1093/oep/55.2.265

Krugman, P. (1994). The Age of Diminishing Expectations: US Economic Policy in the 1990s. Cambridge: MIT Press.

Kumbhakar, S. C., \& Wang, H. J. (2005). Estimation of Growth Convergence Using a Stochastic Production Frontier Approach. Economics Letters, 88, 300-305. https://doi.org/10.1016/j.econlet.2005.01.023

Levine, R. (1997). Financial Development and Economic Growth: Views and Agenda. Journal of Economic Literature, 35, 688-726.

Levine, R. (2004). Finance and Growth: Theory and Evidence. NBER Working Paper 10766. Cambridge, United States: National Bureau of Economic Research.

Lovell, C. A. K. (1996). Applying Efficiency Measurement Techniques to the Measurement of Productivity Change. Journal of Productivity Analysis, 7, 329-340. https://doi.org/10.1007/BF00157047

Lucas, R. (1990). Why doesn't Capital Flow from Rich to Poor Countries? American Economic Review, 80, 92-96.

Martin P. (1991). Labor Migration: Theory and Reality. In P. Martin \& D. Papademetriou (Eds.), The Unsettled Relationship: Labor Migration and Economic Development (pp. 27-42). NY: Greenwood Press.

Maudos, J., Pastor, J. M., \& Serrano, L. (1999). Total Factor Productivity Measurement and Human Capital in OECD Countries. Economics Letters, 63, 39-44. https://doi.org/10.1016/S0165-1765(98)00252-3

Meyers, S., \& Marquis, D. G. (1969). Successful Industrial Innovation. National Science Foundation, Washington.

Mohammed, E., \& Hussain, M. H. (2017). Empirical Analysis of the Relationship between Money Supply and Per Capita GDP Growth Rate in Bangladesh. Journal of Advances in Economics and Finance, 2(1), 54-66. https://doi.org/10.22606/jaef.2017.21005

Montiel, P. J. (2006). Workers' Remittances and the Long-Run Equilibrium Real Exchange Rate: Analytical Issues, Williams College, mimeo.

Peretto P. F. (1998). Technological Change and Population Growth. Journal of Economic Growth, 3(4), 283-311. https://doi.org/10.1023/A:1009799405456

Rao, D. S. P., \& Coelli, T. (1999). Economic Growth, Productivity Change and Inequalty: Methodology for the Assessment of Economic Performance of Nations. Armidale: University of New England/Department of Econometrics/Centre for Efficiency and Productivity Analysis, August

Ratha, D. (2003). Workers Remittance: An important and stable source of Development Finance. Global Development Finance, 157-175. Washington. DC: World Bank

Ratha, D. (2007). Leveraging Remittances for Development. Policy Brief, Migration Policy Institute, Washington DC. Paper presented at the Leading Group on Solidarity Levies Conference on Innovative Finance, Oslo, February 6-7, 2007. 
Restuccia, D., \& Rogerson, R. (2007). Policy Distortions and Aggregate Productivity with Heterogeneous Plants. NBER Working Paper 13018. Cambridge, United States: National Bureau of Economic Research. https://doi.org/10.3386/w13018

Rosenberg, N., \& Mowery, D. (1978). The Influence of Market Demand upon Innovation: A Critical Review of some Recent Empirical Studies. Research Policy, 8.

Schumpeter, J. (1912). The Theory of Economic Development: An Inquiry into Profits, Capital, Credit, Interest and the Business Cycle.

Senbetta, A. (2013). Remittances and sources of growth. Applied Economics Letters, 20(6), 572-580. https://doi.org/10.1080/13504851.2012.718057

Skeldon, R. (2002). Migration and poverty. Asia-Pacific Population Journal, 17(4), 67-82.

Solow, R. (1956). A Contribution to the Theory of Economic Growth. Quarterly Journal of Economics, 70(1), 65-94. https://doi.org/10.2307/1884513

Stojanov, R., Strielkowski, W., \& Drbohlav, D. (2011). Labour Migration and Remittances: Current Trends in Times of Economic Recession. Geografi e, 116(4), 375-400.

Straubhaar, T., \& Vadean, F. P. (2006). International immigrant remittances and their role in development (pp. 139-161). International Migration Outlook, OECD, Paris.

Suh, N. P. (1985). Manufacturing and Productivity. Innovations in Materials Processing (pp. 9-52). Plennum Press New York. 1985. https://doi.org/10.1007/978-1-4613-2411-9_2

Taskin, F., \& Zaim, O. (1997). Catching-up and Innovation in High -and Low- Income Countries. Economics Letters, 54, 93-100. https://doi.org/10.1016/S0165-1765(97)00004-9

Vandenbussche, J., Aghion, P., \& Meghir, C. (2006). Growth, Distance to Frontier and Composition of Human Capital. Journal of Economic Growth, 11, 97-127. https://doi.org/10.1007/s10887-006-9002-y

World Bank. (2005). Global Economic Prospects 2006: Economic Implications of Remittances and Migration. Washington, DC.

Zellner, A. (1962). An Efficient Method of Estimating Seemingly Unrelated Regressions and Tests for Aggregation Bias. J. Am. Stat. Assoc., 57, 348-368. https://doi.org/10.1080/01621459.1962.10480664

Zellner, A. (1963). Estimators for Seemingly Unrelated Regressions: Some Exact Finite Sample Results. J. Am. Stat. Assoc., 58, 977-992. https://doi.org/10.1080/01621459.1963.10480681

Zellner, A. (2006). Seemingly Unrelated Regressions. International Encyclopedia of Social Sciences. H.G.B. Alexander Research Foundation, Graduate School of Business, University of Chicago. Paper 0601 February 2006 University of Chicago.

Zerfu, D. (2007). Governance and Productivity: Microeconomic Evidence from Ethiopia. International Conference on African Development Archives, Center for African Development Policy Research No. $8-2007$.

\section{Appendix A}

\section{Twenty-three countries in Africa employed in the study}

\begin{tabular}{lccc}
\hline No & Country & No & Country \\
\hline 1 & Benin & 13 & Morocco \\
2 & Botswana & 14 & Mozambique \\
3 & Central African Republic & 15 & Niger \\
4 & Cameroon & 16 & Nigeria \\
5 & Côte dIvoire & 17 & Senegal \\
6 & Egypt & 18 & South Africa \\
7 & Gabon & 19 & Sudan \\
8 & Gambia & 20 & Tanzania \\
9 & Ghana & 21 & Togo \\
10 & Kenya & 22 & Tunisia \\
11 & Malawi & 23 & Uganda \\
12 & Mali & & \\
\hline
\end{tabular}




\section{Appendix B}

Table showing significance of pairwise correlations

\begin{tabular}{|c|c|c|c|c|c|c|c|c|c|c|}
\hline & $\begin{array}{l}\text { Technical } \\
\text { change }\end{array}$ & $\begin{array}{l}\text { Technical } \\
\text { efficient }\end{array}$ & RemGdp & $\mathrm{HC}$ & $\begin{array}{l}\text { Broad } \\
\text { Money }\end{array}$ & $\begin{array}{l}\text { Gdp } \\
\text { growth }\end{array}$ & Polity2 & $\begin{array}{c}\text { Population } \\
\text { growth }\end{array}$ & manufacturing & Invest \\
\hline Technical change & 1 & & & & & & & & & \\
\hline Technical efficiency & -0.5244 & 1 & & & & & & & & \\
\hline Remittance/Gdp & $0.0149 * *$ & $-0.0256^{* *}$ & 1 & & & & & & & \\
\hline Human Capital & $-0.0102 * * *$ & $0.0149 * *$ & -0.1412 & 1 & & & & & & \\
\hline Broad Money & $0.0799 *$ & -0.1147 & 0.3352 & 0.3193 & 1 & & & & & \\
\hline Gdpgrowth & $-0.0926^{*}$ & 0.2276 & $0.0537 * *$ & $0.044 * *$ & $-0.0214 * *$ & 1 & & & & \\
\hline Polity2 & $-0.0588^{*}$ & $0.0682 *$ & -0.1545 & 0.1729 & $-0.0529 * *$ & 0.1264 & 1 & & & \\
\hline Poplation growth & $-0.0137 *$ & $0.0092^{* * *}$ & $0.0203^{* *}$ & -0.4312 & -0.5894 & $0.0642 *$ & $0.0625^{*}$ & 1 & & \\
\hline Manufacturing & $0.0486^{* *}$ & $-0.0885^{*}$ & $0.0934^{*}$ & $0.0824 *$ & 0.5202 & -0.1079 & -0.2028 & -0.4084 & 1 & \\
\hline Investment & $0.0169 * *$ & $-0.055^{* *}$ & $0.0391 * *$ & 0.2292 & 0.2924 & 0.1174 & 0.1112 & -0.1453 & 0.0018 & 1 \\
\hline
\end{tabular}

\section{Copyrights}

Copyright for this article is retained by the author(s), with first publication rights granted to the journal.

This is an open-access article distributed under the terms and conditions of the Creative Commons Attribution license (http://creativecommons.org/licenses/by/4.0/). 